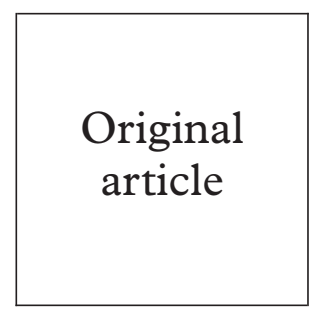

Institut d'Hygiène Sociale, (IHS), Dakar, Sénégal

K Seck

N Samb

A Coll-Seck

I Ndoye

Laboratoire

Rétrovirus, Institut de

Recherche pour le

Développement (IRD)

Montpellier, France

and University of

Montpellier

S Tempesta

C Mulanga-Kabeya

E Delaporte

Centre Hospitalier

Universitaire de Fann

(CHU/Fann), Dakar,

Sénégal

P S Sow

Centre Hospitalier

Universitaire Le

Dantec (CHU Le

Dantec), Dakar,

Sénégal

S Mboup

Institut de Médecine et d'Epidémiologie Africaines, Paris,

France

D Henzel

Correspondence to:

E Delaporte, Research Unit

36, Institut de Recherche

pour le Développement/IRD,

911 Av Agropolis, 34032

Montpellier, France

Eric.Delaporte@mlp.ird.fr

Accepted for publication 8 March 2001

\title{
Prevalence and risk factors of cervicovaginal HIV shedding among HIV-1 and HIV-2 infected women in Dakar, Senegal
}

Karim Seck, Ngone Samb, Serge Tempesta, Claire Mulanga-Kabeya, Daniel Henzel, Papa Salif Sow, Awa Coll-Seck, Souleymane Mboup, Ibrahima Ndoye, Eric Delaporte

Objectives: To assess the risk determinants and prevalence of cervicovaginal shedding of HIV-1 and HIV-2 among women in Dakar, Senegal.

Methods: We conducted a cross sectional study of 153 HIV seropositive female sex workers (FSW) and another 142 HIV seropositive women attending an infectious diseases unit, based on an interview, physical examination, and laboratory screening for major sexually transmitted infections (STI). Cervicovaginal lavage fluid was tested for HIV-RNA by means of nested PCR. Links between cervicovaginal shedding of HIV-1 and HIV-2 and sociodemographic, clinical, and laboratory variables were identified by using odd ratios and $95 \%$ confidence intervals. Logistic regression analysis was used to identify independent links with HIV shedding.

Results: The detection rate of HIV-RNA in cervicovaginal lavage fluid was low among FSW, with no difference between HIV-1 (7/90: $\%$ ) and HIV-2 (3/48: 6\%). The rate was far higher among the other women $(41 \%, 48 / 117 ; 33 \%, 7 / 21$ for HIV-1 and HIV-2, respectively). In multivariate analysis, high plasma viral load $(>40000 \mathrm{copies} / \mathrm{ml})(\mathrm{AOR}=2.4(1.0-5.6) \mathrm{p}=0.04)$ and basic vaginal $\mathrm{pH}(\mathrm{AOR}=2.2(1.3-3.7) \mathrm{p}=0.002)$ were independently associated with HIV-1 shedding. For HIV-2 a CD4 count $<200$ cells $\times 10^{6} / 1$ was the only factor associated with the shedding of HIV-2 (AOR = $9.0(0.9-93)$ ). The genital shedding rate was higher with HIV-1 than with HIV-2 $(\mathrm{OR}=2.1(0.9-4.8)$, but this difference disappeared after adjustment for the CD4+ cell count $(\mathrm{AOR}=1.2(0.5-2.9))$.

Conclusion: Advanced disease stage and immunosuppression are the major risk determinants for shedding of both HIV-1 and HIV-2. Basic vaginal $\mathrm{pH}$ is also a risk determinant for HIV-1 shedding. (Sex Transm Inf 2001;77:190-193)

Keywords: cervicovaginal shedding; HIV; Senegal

\section{Introduction}

In sub-Saharan Africa HIV is mainly transmitted heterosexually and perinatally. Factors influencing HIV shedding in the genital tract are thus likely to be important risk determinants. It was recently shown that HIV-1 viral load correlates with the risk of sexual transmission. ${ }^{1}$ It is also known that factors such as advanced disease stage, CD4+ lymphocyte depletion, vitamin A deficiency, certain sexually transmitted infections (STI), and pregnancy are associated with genital shedding of HIV $-1 .^{2-5}$ The relative contribution of these factors could be influenced by viral, host, and/or environmental characteristics. ${ }^{6}$ Effective strategies to prevent both perinatal and heterosexual transmission must take into account genital shedding of HIV-1. HIV-2 appears to be less infective than HIV-1, and there have been few studies on the determinants of its genital shedding.

We conducted a cross sectional study aimed at identifying risk factors for HIV-1 and HIV-2 genital shedding among women living in Dakar, Senegal, where both viruses are prevalent.

\section{Population and methods}

STUDY POPULATION AND DATA COLLECTION

A cross sectional study was conducted in 1997 among two populations of HIV seropositive women consecutively recruited in Dakar, Senegal. The first population consisted of 153 asymptomatic female sex workers (FSW) enrolled during a routine medical visit at the Institut d'Hygiène Sociale (IHS). The second group comprised 142 women attending the infectious diseases unit of Fann hospital.

With their informed consent, the women were interviewed on their sociodemographic characteristics, sexual behaviour, obstetric history, contraceptive use, and clinical signs. A physical examination was carried out to define the clinical stage of HIV infection according to the 1993 CDC classification, and a gynaecological examination was performed. Cervicovaginal lavage fluid was collected after the sampling for STI as follows: $10 \mathrm{ml}$ of phosphate buffered saline (PBS) was injected into the genital tract, and at least $5 \mathrm{ml}$ of fluid was aspirated 1 minute later, then stored at $-70^{\circ} \mathrm{C}$ until viral RNA assay.

\section{LABORATORY PROCEDURES}

Trichomonas vaginalis and Candida albicans were detected by direct microscopic examination of a wet mount and after Gram staining. The $\mathrm{pH}$ of the vaginal fluid was measured with commercial $\mathrm{pH}$ paper $(\mathrm{pH} 4.0-7.0)$.

Neisseria gonorrhoeae was identified by growth on modified Thayer-Martin medium. Chlamydia trachomatis antigen was detected 
Table 1 Demographic and clinical characteristics of the study population

\begin{tabular}{|c|c|c|c|c|c|}
\hline & $F S W(n=153)$ & $\%$ & Patients $(n=142)$ & $\%$ & $p$ Value \\
\hline \multicolumn{6}{|l|}{ (1) Sociodemographic characteristics } \\
\hline Mean age (range) & \multicolumn{2}{|l|}{37.9 years $(21-59)$} & \multicolumn{2}{|l|}{32.8 years $(16-55)$} & $<0.001$ \\
\hline Nationality: Senegalese & 113 & 74 & 137 & 96 & $<0.001$ \\
\hline \multicolumn{6}{|l|}{ Contraceptive use } \\
\hline None & 138 & 90.2 & 130 & 91.5 & NS \\
\hline Hormonal & 14 & 9.1 & 11 & 7.7 & NS \\
\hline IUD & 5 & 3.2 & 1 & 0.7 & NS \\
\hline Mean number of pregnancies & 4 & & 3.5 & & NS \\
\hline \multicolumn{6}{|l|}{ (2) Cervical and vaginal conditions } \\
\hline Abnormal vaginal discharge & 83 & 55.7 & 118 & 83 & $<0.001$ \\
\hline Mean vaginal $\mathrm{pH}$ & 5.5 & & 5.23 & & $<0.001$ \\
\hline Vaginal ulceration & 13 & 8.6 & 17 & 11.9 & NS \\
\hline Cervical ulceration & 22 & 14.6 & 50 & 35.2 & $<0.001$ \\
\hline \multirow{2}{*}{\multicolumn{6}{|c|}{ (3) Laboratory data }} \\
\hline & & & & & \\
\hline \multirow[t]{2}{*}{ Mean CD 4 lymphocytes $\times 10^{6} / 1$ : } & \multirow{2}{*}{\multicolumn{2}{|c|}{$\begin{array}{l}(\mathrm{n}=137) \\
595\end{array}$}} & \multirow{2}{*}{\multicolumn{2}{|c|}{$\begin{array}{l}(\mathrm{n}=117) \\
271\end{array}$}} & \\
\hline & & & & & $<0.001$ \\
\hline \multicolumn{6}{|l|}{ CD4 category } \\
\hline$>500$ & 71 & 51.8 & 21 & 17.9 & $\chi^{2}=55.7$ \\
\hline $500-200$ & 53 & 38.6 & 39 & 33.3 & $\mathrm{p}<0.001$ \\
\hline$<200$ & 13 & 9.4 & 57 & 48.7 & \\
\hline \multirow[t]{2}{*}{ Mean HIV plasma viral load } & \multirow{2}{*}{\multicolumn{2}{|c|}{$\begin{array}{l}(\mathrm{n}=94) \\
33520 \text { copies } / \mathrm{ml}\end{array}$}} & \multirow{2}{*}{\multicolumn{2}{|c|}{$\begin{array}{l}(\mathrm{n}=116) \\
172680 \text { copies } / \mathrm{ml}\end{array}$}} & \\
\hline & & & & & $<0.001$ \\
\hline \multicolumn{6}{|l|}{ Viral load category } \\
\hline$<200$ & 19 & 20.2 & 15 & 12.9 & $<0.001$ \\
\hline $200-40000$ & 54 & 57.4 & 42 & 10.3 & \\
\hline$>40000$ & 21 & 22.3 & 59 & 50.8 & \\
\hline \multicolumn{3}{|l|}{ AIDS clinical stage (CDC 93) } & \multicolumn{3}{|l|}{$(\mathrm{n}=139)$} \\
\hline A & 153 & 100 & 77 & 55.3 & \\
\hline B & 0 & & 17 & 12.2 & \\
\hline $\mathrm{C}$ & 0 & & 45 & 32.3 & \\
\hline Mean serum vitamin A level $(\mu \mathrm{mol} / \mathrm{l})$ & 0.94 & & 0.66 & & $<0.001$ \\
\hline \multicolumn{6}{|l|}{ (4) STIs } \\
\hline Syphilis & 51 & 33.3 & 3 & 2.1 & $<0.001$ \\
\hline Trichomonas vaginalis & 15 & 9.8 & 11 & 7.7 & NS \\
\hline Chlamydia trachomatis & 14 & 9.1 & 3 & 2.1 & NS \\
\hline Candida albicans & 20 & 13 & 22 & 15.4 & NS \\
\hline$N$ gonorrhoeae & 9 & 5.8 & 5 & 3.5 & NS \\
\hline HIV-1 & 90 & 58.8 & 117 & 82.3 & $<0.001$ \\
\hline HIV-2 & 48 & 31.3 & 21 & 14.7 & $<0.001$ \\
\hline $\mathrm{HIV} 1+2$ & 15 & 9.8 & 4 & 2.8 & $<0.01$ \\
\hline
\end{tabular}

with an enzyme immunoassay (EIA, Microtrack, II Syva, France). Syphilis was diagnosed by the RPR (Becton Dickinson) and TPHA tests (Fujirebio, Tokyo, Japan).

Screening for anti-HIV antibodies was performed using a rapid test (Capillus $\mathrm{HIV}-1 / 2$, Cambridge Diagnostic, Ireland) and a line immunoassay (Innolia HIV1/2, Innogenetics, Belgium). CD4+ lymphocytes were counted by flow cytometry using a FACScan (BectonDickinson). The vitamin A concentration was determined by high performance liquid chromatography.

Viral load in plasma was quantified only in HIV-1 infected women, using the Amplicor HIV-1 Monitor kit, version 1.5 (Roche Diagnostic, NJ, USA).

Qualitative assay of HIV-1 and HIV-2 RNA in cervicovaginal lavage fluid was performed by nested PCR amplification of the pol region, as previously described. ${ }^{3}$

DATA ANALYSIS

Dbase 5, EPI-INFO (version 6.0, Centers for Diseases Control and Prevention, Atlanta, GA, USA), and Logistic Regression software (3.11 Ef Dallalge, Andover, USA) was used for data analysis. Proportions and rates were compared by using the $\chi^{2}$ and Fisher's exact test, and means were compared using Student's $t$ test. Variables associated with HIV cervicovaginal shedding in univariate analysis $(p<0.25)$, and forced variables, were included in a multiple logistic regression model. Adjusted odd ratios (AORs) and 95\% CIs were calculated using logistic regression parameters. The HosmerLemeshow statistic was used to assess the fit of the final model.

\section{Results}

CHARACTERISTICS OF THE STUDY POPULATION Table 1 summarises the sociodemographic data and the prevalence of major STIs in the two population groups.

All the FSW enrolled in the study were officially registered according to the Senegalese law. Their average number of clients per week was 11.0 (range 1-35). All were asymptomatic, with higher CD4+ cell counts and lower plasma viral load than the other group of women $(\mathrm{p}<0.001)$.

The rates of STI were low in both groups. However, $33 \%$ of the female sex workers and only $2 \%$ of the other women were seropositive for syphilis. HIV-1 infection predominated in both groups. HIV-2 infection and dual HIV-1/2 seropositivity were more frequent in the female sex workers than in the other women $(\mathrm{p}<0.001)$.

The prevalence of HIV RNA shedding was low among the female sex workers, with no difference between HIV-1 (7/90 (7.8\%)) and HIV-2 (3/48 (6.2\%)). It was far higher in the other women $(41 \%, 48 / 117 ; 33.3 \%, 7 / 21$ for HIV-1 and HIV-2, respectively); HIV-1 shedding was more frequent than HIV-2 shedding in these women $(\mathrm{OR}=4.1(1.6-10.9))$. HIV shedding was not detected in any women with dual HIV-1/2 seropositivity (15 female sex workers, four other women). Because of the 
Table 2 Univariate correlates of cervicovaginal HIV-1 and HIV-2 shedding

\begin{tabular}{|c|c|c|c|c|c|c|c|c|}
\hline \multirow[b]{2}{*}{ Variables } & \multicolumn{4}{|c|}{$H I V-1$ shedding } & \multicolumn{4}{|c|}{ HIV-2 shedding } \\
\hline & $\begin{array}{l}\text { Positive } \\
(n=55)\end{array}$ & $\begin{array}{l}\text { Negative } \\
(n=152)\end{array}$ & OR 95\% CI & $p$ Value $^{*}$ & $\begin{array}{l}\text { Positive } \\
(n=10)\end{array}$ & $\begin{array}{l}\text { Negative } \\
(n=59)\end{array}$ & OR 95\% CI & $p$ Value $^{\star}$ \\
\hline Vaginal pH (mean) & 5.7 & 5.35 & & $<0.001$ & 5.4 & 5.4 & & 1.0 \\
\hline Vaginal discharge & $45 / 53$ & $104 / 150$ & $2.2(0.9-5.3)$ & 0.05 & $9 / 10$ & $34 / 58$ & $6.3(0.7-14.3)$ & 0.06 \\
\hline Genital ulceration & $24 / 55$ & $38 / 149$ & $2.2(1.1-4.6)$ & 0.01 & $5 / 10$ & $12 / 58$ & $3.7(0.7-19.3)$ & 0.06 \\
\hline CD 4 count $<200 \times 10^{6} / 1$ & $27 / 45$ & $35 / 135$ & $4.1(1.9-9.0)$ & $<0.001$ & $4 / 9$ & $2 / 52$ & $18.1(2.1-24.8)$ & 0.003 \\
\hline Plasma viral load $>40000$ & $34 / 55$ & $45 / 144$ & $3.6(1.8-7.2)$ & $<0.001$ & ND & ND & & \\
\hline Serum vitamin $\mathrm{A}<0.07 \mu \mathrm{mol} / 1$ & $24 / 41$ & $47 / 105$ & $1.7(0.8-3.9)$ & 0.13 & $7 / 18$ & $15 / 47$ & $4.8(0.9-29.2)$ & 0.02 \\
\hline AIDS clinical stage (stage C) & $28 / 53$ & $17 / 131$ & $6.01(2.7-13.6)$ & $<0.001$ & $2 / 10$ & $1 / 59$ & $14.5(0.6-869)$ & $>0.05$ \\
\hline
\end{tabular}

$\mathrm{OR}=$ odds ratio

$\mathrm{CI}=$ confidence interval

${ }^{\star} \chi^{2}$ test.

$\mathrm{ND}=$ not done.

low number of such women they were excluded from the analysis.

\section{CORRELATES OF GENITAL HIV SHEDDING (TABLE} 2)

Mean age was higher among HIV-2 infected women than among HIV-1 infected women (39 versus 34 years; $p<0.001$ ) and the former were less immunodepressed (mean CD4+ cell count 637 versus $\left.379 \times 10^{6} / 1, \mathrm{p}<0.001\right)$. Vaginal ulceration and cervical ectopy were more frequent among HIV-1 seropositive women.

In univariate analysis, HIV-1 shedding was associated with CD4+ cell counts below 200, advanced HIV disease and high plasma viral load.

Vaginal discharge $(\mathrm{OR}=2.2(0.9-5.3))$, genital ulceration $(\mathrm{OR}=2.2(1.1-4.6))$, and basic vaginal $\mathrm{pH}$ were also associated with HIV-1 shedding.

In multivariate analysis, high plasma viral load $(\mathrm{AOR}=2.4(1.0-5.6) \mathrm{p}=0.04)$ and basic vaginal $\mathrm{pH}(\mathrm{AOR}=2.2(1.3-3.7) \mathrm{p}=0.002)$ were independently associated with HIV-1 shedding. The Hosmer-Lemeshow statistic showed a good fit of the final model $(c=6.6$; $=0.58$ ).

In univariate analysis, HIV-2 shedding was associated with older age $(p=0.03)$, severe vitamin A deficiency, advanced HIV disease and CD4+ cell counts below 200 .

In multivariate analysis the only factor associated with HIV-2 shedding was a CD4+ cell count below 200 (AOR $=9.0(0.9-93)$ ) (Homesher-Lemeshow statistic $=0.55, \mathrm{p}=$ 0.76)

HIV-1 shedding was more frequent than HIV-2 shedding $(\mathrm{OR}=2.1(0.9-4.8)$ ), but not after adjustment for the CD4+ cell count around a cut-off of $200 \times 10^{6} / 1$ (AOR $=1.2$ $(0.5-2.9))$.

\section{Discussion}

This study shows that the rates of cervicovaginal shedding of HIV-1 and HIV-2 among infected Senegalese women are similar after adjustment for the HIV disease stage.

Few studies have addressed the risk factors for cervicovaginal HIV-2 shedding. ${ }^{3}$ We found that HIV-2 RNA was detectable by PCR in cervicovaginal lavage fluid from $14.5 \%$ of 69 HIV-2 infected women. The presence of HIV-1 and HIV-2 RNA in the genital tract was clearly associated with factors reflecting HIV disease progression such as CD4+ lymphocyte depletion; this was well known for HIV-1 but not for HIV-2. Like HIV-1, female genital HIV-2 shedding is probably associated with a high circulating viral load. Therefore, risk determinants for cervicovaginal shedding of HIV are a function of the disease progression and the viral level rather than the virus type suggesting that the low sexual transmission rate of HIV-2 reported $^{7}$ could be explained by the slow disease progression, which characterised the HIV-2 infection. This is also the likely reason for the low rate of vertical transmission of HIV$2 .^{8}$

STIs are well established cofactors for sexual transmission of HIV-1. We observed a weak association between vaginal ulceration and HIV-1 shedding in the genital tract. No correlation was observed between the presence of any specific STI and cervicovaginal shedding of HIV-1 or HIV-2. This may be partly explained by the low prevalence of STIs in our population, and their treatment, as treatment of STIs reduces the prevalence of HIV-RNA detection in the female genital tract. ${ }^{3}$

The lack of any association between cervicovaginal HIV shedding and oral contraceptive use or cervical ectopy may be due to their low prevalence in the study population, and to its small size.

Most women in our study were deficient in vitamin $\mathrm{A}$, and we found no correlation with HIV shedding.

The prevalence of cervicovaginal HIV-1 shedding increased with the vaginal $\mathrm{pH}$ (ranging from 5.0 to 5.9 ). Increased vaginal $\mathrm{pH}$ could result from bacterial vaginosis, a factor associated with susceptibility to sexual HIV transmission in women. ${ }^{9-11}$ Alternatively, traditional product for local vaginal hygiene may also increase $\mathrm{pH}$.

In conclusion, our results show that advanced HIV disease stage is the main risk determinant for female genital shedding of both HIV-1 and HIV-2. HIV-1 shedding was also associated with higher vaginal $\mathrm{pH}$.

This work was sponsored by a grant from the Agence Nationale de Recherche sur le SIDA (ANRS/MAE, Projet SIDAK).

Contributors: KS was responsible for the care of the FSW, for supervising the study in Senegal, and for preparing the manuscript; NS and SM supervised laboratory testing at CHU Le Dantec; DH and ST were responsible for statistical analysis; ACS was responsible for supervising the study at CHU Fann; ACS was responsible for supervising the study at CHU Fann;
and SPS was the senior clinician at CHU/Fann; IN was the and SPS was the senior clinician at CHU/Fann; IN was the
principal investigator in Senegal; ED was responsible for the principal investigator in Senegal; ED was responsible for the
study design, supervision, and for preparing the manuscript. 
1 Quinn T, Werver M, Sewankambo, et al. Viral load and heterosexual transmission of human deficiency virus type $1 . N$ Engl f Med 2000:342:921-9.

2 Mostad SB, Overbaugh J, DeVange DM, et al. Hormonal contraception, vitamin A deficiency, and other disk factors for shedding of HIV-1 infected cells from the cervix and vagina. Lancet 1997;350:922-7.

3 Ghys PD, Fransen K, Diallo MO, et al. The associations between cervicovaginal HIV shedding, sexually transmitted diseases and immunosuppression in female sex workers in Abidjan, Côte d'Ivoire. AIDS 1997;11:F85-93.

4 Loussert Ajaka I, Mandelbrot L, Delmas MC, et al. HIV-1 detection in cervicovaginal secretions during pregnancy. AIDS 1997;11:1575-81.

5 Hart CE, Lennox JL, Pratt-Palmore M, et al. Correlation of human immunodeficiency virus type 1 RNA levels in blood and the female genital tract 7 Infect Dis 1999;179:871-82.

6 Royce RA, Sena A, Cates Willard, et al. Sexual transmission Royce RA, Sena A, Cates Willard, et al. Sexur
of HIV. N Engl f Med 1997;336:1072-8.
7 De Cock KM, Adjorlolo G, Ekpini E, et al. Epidemiology and transmission of HIV-2. Why there is no HIV-2 pandemic. fAMA 1993;270:2083-6.

8 Adjorlolo-Johnson G, De Cock K, Ekpini E, et al. Prospective comparison of mother-to-child transmission of HIV-1 and HIV-2 in Abidjan Ivory Coast. $7 A M A$ 1994;272:4626.

9 Sewankambo N, Gray RH, Wawer MJ, et al. HIV and HIV-2 J infection associated with abnormal vaginal flora morphology and bacterial vaginosis. Lancet 1997;350:546-50.

10 Taha TE Hoover DR, Dallabetta GA, et al. Bacterial vaginosis and disturbances of vaginal flora: association whith increased acquisition of HIV. AIDS 1998;12:1699706.

11 Martin H, Richardson B, Nyange P, et al. Vaginal lactobacilli, microbial flora, and risk of hummunodeficiency virus type 1 and sexually transmitted disease acquisition. $\mathcal{F}$ Infect Dis 1999;180:1863-8.

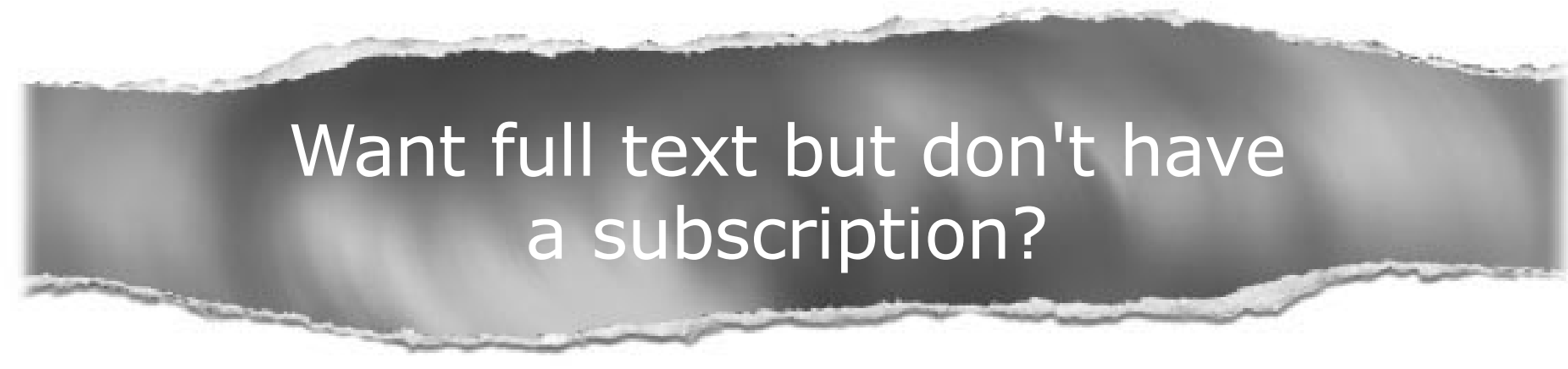

\section{Pay per view}

For just $\$ 8$ you can purchase the full text of individual articles using our secure online ordering service. You will have access to the full text of the relevant article for 48 hours during which time you may download and print the pdf file for personal use.

\section{www.sextransinf.com}

